\title{
FURTHER STUDIES OF THE MARGINS OF SMALL DRY-BASED GLACIERS, McMURDO SOUND AREA, ANTARCTICA \\ (Abstract)
}

by

T.J.H. Chinn

(New Zealand Geological Survey, Christchurch, New Zealand)

Studies of the margin morphology of small fully drybased glaciers of the McMurdo Sound area have been continued in the Terra Nova Bay, Cape Bird (Ross Island), and Dry Valleys areas. Normally, very limited amounts of debris are carried by these glaciers, but some glaciers in the Terra Nova Bay area are found to have large zones of debris-covered ice. Preliminary results indicate that this debris was originally left as a discontinuous sheet of ice-cored Ross Drift following retreat of the Pleistocene Ross Sea I advance of the Ross Ice Shelf. Holocene glacial expansion has formed glaciers by direct accumulation on to areas of ice-cored drift located in hollows. Glaciers thus formed have a till bed entrained by stratigraphy, flow on Pleistocene ice, and disgorge the sediment as a broad ice-cored "inner moraine".

Outlet glaciers of the small Cape Bird ice cap superficially appear to have recently retreated back from large ice-cored moraines at their margins. A reconnaissance has shown that these glaciers are actively advancing and that the extensive debris output was derived from entrained ice-cored drift of the Ross Sea I glaciation which is being re-deposited.

In the Dry Valleys area, a number of glaciers enter enclosed lakes and here the contact between lake ice and glacier ice is permanent and cannot ablate. The lake ice must therefore move with the glacier. This configuration has the possibility of rafting glacial moraine across the lake before it is deposited. Multiple cases of different configurations are possible with either rising or falling lake levels and advancing or receding glaciers. Massive beds of regelation ice, where lake water has frozen on to the glacier sole, have been found at one glacier/lake junction.

\section{SURGE OF WEST FORK GLACIER, ALASKA, U.S.A.}

\section{(Abstract)}

by

Keith Echelmeyer and Will Harrison

(Geophysical Institute, University of Alaska, Fairbanks, AK 99775-0800, U.S.A.)

West Fork Glacier is a large glacier in the central Alaska Range, in the Susitna River drainge system. It is adjacent to, and about the same size as, the surge-type Susitna Glacier. Judging from Washburn photography, the last surge of West Fork Glacier was in the 1930s. Balance and velocity measurements in the early 1980 s indicated that West Fork Glacier has not achieved balance flux, and, judging from its similarity to Susitna Glacier, T. Clarke predicted that its next surge was imminent. Aerial observations by A. Post and R. Krimmel in late August 1987 indicated slight, but anomalous, crevassing which they suggested could be premonitory to a surge.

We noticed, in early January 1988, that the margins of West Fork Glacier were badly sheared. Observations at the end of January indicated more extensive shearing and crevassing, with much of the glacier affected from low in the ablation area to well above the equilibrium line, including some major tributaries. More observations in early February indicated propagation of the areas of draw-down far up into the accumulation area, and a reasonably well-defined front of active ice propagating into the stagnant ice of previous surges. Small lakes were seen at the edge of the propagating front. During the placement of a marker on the lower glacier, the glacier could be felt lurching ahead at about $1 \mathrm{~min}$ intervals.

Water sampling beneath seasonal ice cover of the main streams at the glacier terminus and at about $10 \mathrm{~km}$ below (where all the streams converge into a single channel) indicated "low" flow (there are no base-line data) and no trace of turbidity in the water. No trace of flooding was found in the snow bordering the streams, or in the ice cover. 